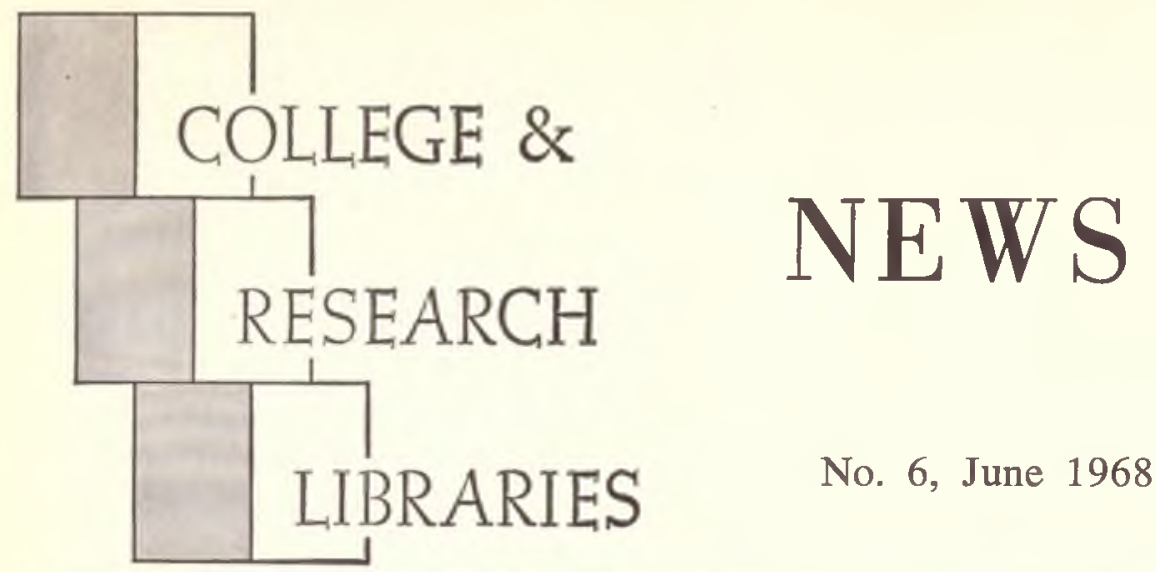

ACRL News Issue (B) of College \& Research Libraries, Vol. 29, No. 3

Geonge M. Bailey, executive secretary of ACRL since November 1, 1963, has resigned from his position effective August 31. The Board of Directors of ACRL, in its search for a successor to Mr. Bailey, requests the membership to submit names of candidates to the President, with a copy to the Executive Secretary of ACRL at ALA Headquarters.

The description of the position and qualifications are as follows:

DEsCRIPTION:

The position of Executive Secretary of the division is one of high professional responsibility. It involves provision of staff service to the members to enable them to develop the divisional program; representation of the division and of ALA to other associations, government officials, other professions, and the public at large; and provision of consultant service to administrators and librarians of junior colleges, colleges, universities, and research institutions on the problems of academic libraries. A great deal of travel, public speaking, and writing for publication is involved.

QuALIFICATtONS:

Four years of college plus an MS in LS degree. Appropriate experience and knowledge of materials and activities related to academic libraries; ability to handle detail and to meet deadlines; to make public appearances; and to work cooperatively with a great variety of people.

—James Humphry, III President, ACRL

The Metropolitan Museum of Art New York, New York 10028
George Bailey has served with distinction in the position of Executive Secretary of the Association of College and Research Libraries, the largest division of the American Library Association, for the past five years. When he came to us in 1963 he brought with him the benefit of his library experience at the University of California at Berkeley and Davis, and Northwestern University. George has devoted himself to the cause of improving and helping libraries and librarianship in all the types of institutions the Association represents: junior colleges, colleges, universities, research and special. Although the membership has increased by 65 per cent between 1963 and 1968, with the inevitable increase in the work load, by dint of long hours and hard work, he has kept pace with it. His sense of professionalism, his ability to work with the members as well as his colleagues at headquarters-not to mention "his" president!, are qualities which make him a model executive secretary.

In his new position as librarian and professor at one of the municipally supported institutions of higher education in New York City-York College-George, by his ACRL experience in all its variety, as well as his previous service in libraries, is admirably equipped to develop a first-rate library. We are all agreed that ACRL's and ALA's loss is York's gain. We will miss George in his present post, but we'll put him to work in the Association-in another capacity -when he assumes his new post. It is inevitable, and right, that George should move on to another important library position-we wish him well in the new endeavor and at the same time vote him a rousing and unanimous round of thanks for a singularly outstanding job at ACRL. Speaking selfishly, I'm relieved that my term of office expires before George's; speaking from experience, I'm pleased that Dave Kaser will have been president of ACRL 


\section{YOU CAN BANK ON}

\section{Taylor-Carlisle}

BOOKSELLERS TO THE

for

better

service

ACADEMIC WORLD

Speedy delivery

... your orders processed without delay

Efficient service

... alert, experienced personnel

\section{Huge inventory}

Send for Our Current Discount Schedule

$$
\text { Taylor-Carlisle }
$$

NEW YORK: 115 East 23rd Street

New York, N.Y. 10010

FLORIDA: Winter Park Mall

Winter Park, Florida 
for several weeks before George leaves. To put it another way, working with George in pursuing goals to which we are all devoted, is a privilege and a pleasure.-James Humphry III.

NotE: See profile on pages 194-195.

\section{CONFERENCE NOTES}

- The Research Committees of the Library Education Division of ALA and of the Association of American Library Schools will cosponsor an open program meeting on research in library science at the annual ALA conference in Kansas City, on Wednesday morning, June 26, at 8:00 to 9:30 A.M.

John McCrossan, assistant professor of the department of library science, University of Michigan, Ann Arbor, and program chairman, will preside. Directors of three recent library research projects will describe the organization, research methods, and results of their work.

Mrs. Florence D. Cleary, project director, and Mrs. Ruth Allen, chief investigator, of the College of Education, University of South Florida, Tampa, will report on "The Effect of a Librarian-Centered Reading Guidance Program on the Reading Skills and Habits of Elementary School Pupils."

Haynes McMullen, professor of library science, graduate library school, Indiana University, Bloomington, will report on "The Use of a Computer in the Study of American Libraries in Existence before 1876." A computer was used for sorting data, performing simple arithmetic processes, and producing graphs as an aid in the study of approximately 6800 libraries founded in the United States before 1876. The computer was used because it saved enormous amounts of time in handling data and eliminated many clerical errors that would have resulted from non-computer methods.

Marina E. Axeen, associate professor, department of library science, Ball State University, Muncie, Indiana, will report on "Teaching the Use of the Library to Undergraduates; An Experimental Comparison of ComputerBased Instruction and the Conventional Lecture Method." Two groups of undergraduates were taught an introductory course in library science, one by a computerized program and the other by the conventional lecture methods. Results of the two methods were analyzed and compared. A doctoral dissertation at the University of Illinois.

ACRL Membership April 30, 1968

11,870

April 30, 1967

10,978

April 30, 1966

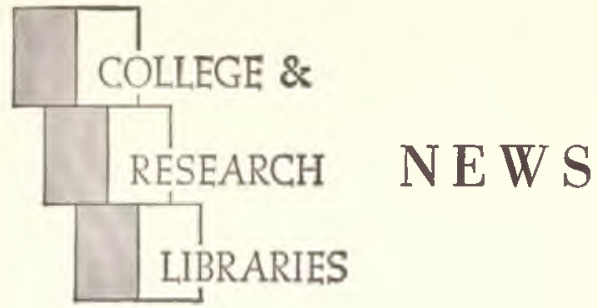

ACRL News Issue of College \& Research Libraries

Editor, David Kaser, Joint University Libraries, Nashville, Tenn. 37203.

Publications Officer, Mary Falvey, $50 \mathrm{E}$. Huron St., Chicago 60611.

ACRL Executive Secretary, George M. Bailey.

ACRL Officers, 1967/68: President, James Humphry III; College Libraries Section Chairman, Audrey North; Junior College Libraries Section, Mrs. Alice B. Griffith; Rare Books Section, Lawrence S. Thompson; Subject Specialists Section, Richard L. Snyder; Agriculture and Biological Sciences Subsection, Mrs. Pauline W. Jennings; Art Subsection, James K. Dickson; Law and Political Science Subsection, Morris Cohen; Slavic and East European Subsection, Jerzy (George) J. Maciuszko; University Libraries Section, Stuart Forth.

Editorial Board: John M. DAwson, University of Delaware; Gustave A. Harnen, Boston University; SamUEL RothsteIN, University of British Columbia; James E. Skipper, Princeton University; Nohman E. Tanis, Kansas State College of Pittsburg; Maurice F. Tauner, Columbia University; EILeEN Thonnton, Oberlin College.

News from the Field, Personnel profiles and notes, classified advertising, official matter of ACRL, and other material of a timely nature is published in the News issues of College \& Research Libraries.

Inclusion of an article or advertisement in CRL does not constitute official endorsement by ACRL or ALA.

Production and Advertising and Circulation office: 50 E. Huron St., Chicago, IlI. 60611. Change of address and orders for subscriptions should be addressed to College \& Research Libraries, for receipt at the above address, at least two months before the publication date of the effective issue.

Subscription to $C R L$ is included in membership dues to $A C R L$ of $\$ 6$ or more; other subscriptions to $C R L$ are $\$ 10$ per year. Neither subscriptions nor memberships include miscellaneous unscheduled supplements, which are available by purchase only. Retroactive subscriptions are not accepted. Single journal copies are available at $\$ 1.50$ each and News issues at $\$ 1.00$ each from ALA Publishing Department.

Indexed in Library Literature. Abstracted in Library Science Abstracts. Book reviews indexed in Book Review Index.

College \& Research Libraries, is the official journal of the Association of College and Research Libraries, a division of the American Library Association; and is published seventeen times per year-bi-monthly as a technical joumal with 11 monthly News issues, combining July-August-at 1201-05 Bluff St., Fulton, Mo. 65251 .

Second-class postage paid at Fulton, Mo. 